\title{
Environmental Security and Waste Management Aspects of the Tisza Floods
}

\section{Tiszai árvizek környezetbiztonsági és hulladékgazdálkodási vonatkozásai}

In this article, the author analyses the environmental safety and waste management tasks of the collection, selection and treatment of driftwood and waste accumulated on the upstream side of the Kisköre Dam as a result of floods. It describes separately the work carried out during the floods of 2017 and 2019, which were outstanding in terms of both volume and duration. It covers changes in the amount and proportions of waste and driftwood and analyses changes in work efficiency.

Keywords: ice flood, domestic waste, waste collection, selection, environmental remediation

A cikkben a szerző az árvizek következtében a Kiskörei Vízlépcső és Duzzasztómü felvizén feltorlódott uszadék és hulladék gyüjtésének, szelektálásának és kezelésének környezetbiztonsági és hulladékgazdálkodási feladatait elemzi. Külön ismerteti a volumenében és időtartamában is kiemelkedő 2017. és 2019. évi árvizek időszakában végzett munkákat. Kitér a hulladék és uszadék mennyiségének és arányainak változására, valamint elemzi a munkák hatékonyságának változását.

Kulcsszavak: jeges árviz, kommunális hulladék, hulladékgyüjtés, szelektálás, környezeti kárelháritás

\section{Introduction}

As it was proven by the cyanide and heavy metal contamination in the year 2000 on the River Tisza, the problem of environmental pollution cannot be solved within the traditional (modern) framework of nation-state sovereignty. For the solution of an environmental crisis, the limitation of nation-state sovereignty and a new type of international cooperation would

Middle Tisza District Water Directorate, Head of Department, e-mail: katona.gabor@kotivizig.hu 
be needed that takes ecological aspects into consideration. ${ }^{2}$ The well-regulated domestic legal framework is useless if international regulations do not protect against potential external negative effects. This applies to both environmental damages caused by waste and the aspects of waste management.

As a result of eco-conscious education and well-organised waste collection and treatment, the extent of abandoned, untreated waste and the number of illegal waste dumps are decreasing in Hungary. Children get to know eco-conscious thinking, selective waste collection and recycling as early as in kindergarten, while in school it is part of their studies. ${ }^{3}$ To support this tendency, a sufficient legal framework should be established and technologies reducing waste-related environmental damages should be used. However, these efforts do not have a long history in Hungary. Until 2000, there was no waste management outline law. Before that the respective provisions were regulated in the general law of environmental protection, and the measures relating to environment threatening and environment damaging are contained by that even today. The first waste management law of Hungary was adopted by the Parliament on 23 May 2000, called Act No. XLIII of 2000 on Waste Management. ${ }^{4}$

It was modified several times, but the most significant change was the introduction of Act CLXXXV of 2012 on Waste, which was actually the establishment of the new waste law on 1 January 2013, and it is still in effect. ${ }^{5}$ The demand for a new law was brought to life by Directive 2008/98/EC that was published by the European Parliament and Council, which obliged the member states to put in effect the measures of the directive within two years, so by now waste management is done according to uniform principles in the legal system of each EU member state.

In spite of the above mentioned measures, environmental damage is still increasing in certain cases. The environmental burden of the driftwood arriving from the upper Tisza did not decline despite the expectations arising from the EU legal harmonisation. In 2019, a waste collecting system started to operate on the upper Tisza. Its task is to direct the larger size and larger amount waste to the floodplain and retain it at a previously selected area. It was installed at a location where waste and driftwood can be collected and held back with artificial obstacles. Following the flood wave, the waste mass can be collected, transported and (on the protected side of the dike) can be selected and handled by machines. To deal with

2 János I Tóth, A tiszai ciánszennyezés. Rendszerszemléletü elemzés [Systemic Analysis of the Tisza Cyanide Pollution] (Szeged, 2002), 244.

3 Ágnes Tarné Venczel, Környezettudatosságra nevelés az óvodában [Environmental Awareness Education in Kindergarten] (MA thesis, Miskolc, 2018), 11.

4 Tímea Nikoletta Nagy, A hulladékgazdálkodás szabályozásának újjogi alapja [The New Legal Basis for the Regulation of Waste Management] (MA thesis, Miskolc, 2015), 6.

5 Ferenc Szabó, 'Implementációs kudarcok és kiigazítási kísérletek a hazai hulladékgazdálkodási politikában' [Implementation Failures and Adjustment Attempts in Domestic Waste Management Policy], Taylor Gazdálkodásés Szervezéstudományi Folyóirat 9, no 2 (2017), 56. 
smaller waste pollution, a redirection point has been formed by floating devices (self-propelled barges) on the right spot of the riverbed, at a slight angle of the flow. The waste stuck at the riverbank can be collected and loaded on trucks or barges by crawler or floating excavators. The lightweight waste floating and spreading on the surface of the main stream is collected with special collecting ships. This technology is capable of the collection of waste and driftwood until the gauge of Vásárosnamény reaches a water level of $600 \mathrm{cms}$. Because of this operating limitation - which makes it impossible or highly limited to use the system until floods - the prevention of environmental damage caused by waste at Lake Tisza and the Kisköre Dam is still unsolved. Besides the environmental risk, it also means a serious expense for the government and could also result in flood risk.

\section{Legal aspects of flood transported waste}

2008/98/EC Directive of the European Parliament and Council sets out measures for the protection of the environment and human health, which is expected to be achieved by the prevention or decreasing of the negative effects of waste production and management, and by decreasing the global effects of resource use and also the enhancement of efficiency. According to this, 'waste' is a material or object, which is or will be discarded by its owner, or they are obliged to discard it; and 'waste management' is the collection, transportation, utilisation and disposal of wastes, including the control of the process, the maintenance of the waste dumps and the related sales and mediating activity. ${ }^{6}$ According to these terms, the Act on Waste mentioned in the Introduction controls waste producing activities, waste management and its facilities in Hungary. The Act sets out basic principles, so for example based on the 'polluter pays' principle, the one producing the waste, owning the waste or manufacturing the product that becomes waste is responsible for covering the costs of handling and managing that waste. According to paragraph 31 (1) of the law, the waste owner should take care of the handling of the waste, during which they make sure it is handed over for handling, transportation, collection or to the public utilities. Paragraph 61 (6) of the Act sets out that the 'environmental protection authority can oblige those who are not willing to fulfil their obligations set out in paragraph [...] 31 (1) to transport and handle the illegally dumped or abandoned waste', furthermore paragraph 61 (3) tates that if the owner of the waste is unknown, according to paragraph 31, the obligation is transferred to the owner of the property where the waste is located, which applies to the majority of waste drifting on the River Tisza. ${ }^{7}$

However, neither the Hungarian nor EU laws rule cases when waste is coming from a different country under uncontrolled conditions. The large quantity of waste coming with driftwood has been causing problems for a long time. In addition to its short-term effects on water quality, also the waste handling tasks need to be done. This is set out by Government Decree 90/2007

2008/98/EC Directive of the European Parliament and Council.

2012. évi CLXXXV. törvény a hulladékról [Act CLXXXV of 2012 on Waste]. 
(IV. 26.), according to which the competent water directorate is responsible for controlling the operation of prevention and protection against environmental damage in case of surface waters and water management facilities. Damage control should be done in different alert levels. According to the alert levels, in level I the exploration of environment damage; in level II the preparation of operation; in level III the execution of damage control activity should be done. ${ }^{8}$ On the middle Tisza, these activities belong to the Middle Tisza District Water Directorate. However, the collection of waste is not only needed to fulfil the legal obligations. Plastic production often uses dangerous additives, and also the fast reproduction of waste generates an extreme increase in quantity. Degradation caused by UV is very slow and it is even slower in water, meanwhile plastic falls apart to tiny bits which bind chemical contaminations this way, building them into the ecosystems. 90 per cent of floating marine waste and $60-80$ per cent of the total marine waste consists of plastic. ${ }^{9}$ It is out of question that plastic should be removed from the environment, as it is also obvious that if we miss doing that they will flow downstream and will accumulate in the oceans as part of one of the large waste islands. ${ }^{10}$

\section{Experience gained during the ice flood of 2017}

The ice flood of 2017 was accompanied by a never experienced amount of drifting waste. Managing an ice flood itself is a challenge, which requires special attention regarding flood protection activities.

As a result of congestion, ice can create an obstacle for the flow, the damming effect of which can be eliminated with the use of ice breaking ships and even explosives in some cases. The explosion of ice dams is one of the most dangerous tasks. In the event of an ice jam when the damming effect creates a difference in the water level, the operation should be organised by the instructor of explosion in a way that ensures constant monitoring of the ice dam so even its slightest movement can be reported to the persons working on the ice to allow them to escape in time. ${ }^{11}$ This dangerous operation is made even worse by the uncertainty caused by the waste through the unpredictable consequences of moving on the ice dam and of the detonation. It is also impossible to identify the origin and composition of unknown material accumulated (Figure 1), which can threaten human health.

8 90/2007. (IV. 26.) Korm. rendelet a környezetkárosodás megelőzésének és elhárításának rendjéről [Government Decree 90/2007 (IV. 26.) on procedures for the prevention and remedying of environmental damage].

9 István Gubek, 'A tengerek és óceánok mủanyag szennyezésének komplex hatása - 1. rész: A probléma bemutatása' [The complex impact of plastic pollution of the seas and oceans - Part 1: Description of the problem], Természetvédelmi Közlemények 22 (2016), 35.

10 Jambeck et al., 'Plastic waste inputs from land into the ocean', Science 347, no 6223 (2015), 768.

11 Norbert Daruka, 'Jégvédekezés robbantással' [Ice protection by blasting], Müszaki Katonai Közlöny 24, no 4 (2014), 63. 


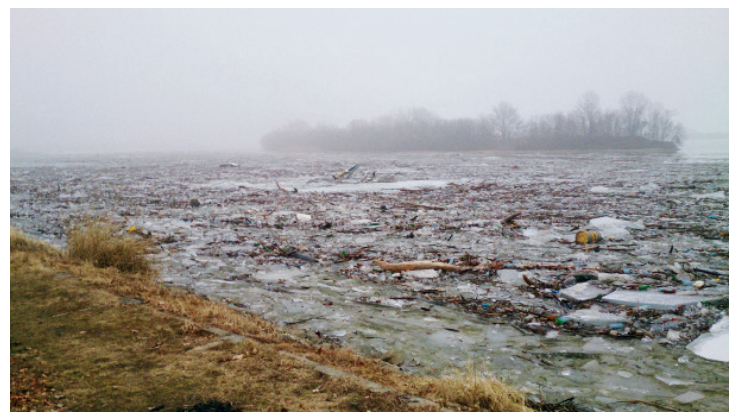

Figure 1. Waste floating with ice

Source: Compiled by the author.

An additional problem of waste coming down the river is that it gets into the retention areas with the flood wave and gets deposited there. After multiple floods, this results in accumulated waste, which contributes to the filling up of the retention area with material of environmental hazard. Hence the collection of drifted material in the floodplains is also needed, which is a very challenging task to organise because of the large size of the area.

In the event of a flood wave, the driftwood and waste is able to float through the open structures of the Kisköre Dam smoothly. However, in order to maintain the seasonal operational water level or to prevent overdrainage of the reservoir, the floodgates get closed in the falling limb of the flood to start damming. This is the time driftwood starts to accumulate, which should be collected first to make us able to select the waste. The extraction of driftwood from the water is possible in the falling limb with the use of ships in the foreground of the flood side of the dike, while the driftwood and waste remaining on dry surface after the flood can be collected and transported to the authorised waste dumps using serious amounts of labour and machinery. The composition of driftwood and waste extracted in the year 2017 is shown in Tables 1 and 2 .

Table 1. Quantity and composition of waste extracted after the 2017 ice flood

\begin{tabular}{|c|c|c|}
\hline \multicolumn{2}{|c|}{ Quantity and composition of waste extracted after the 2017 ice flood } \\
\hline Communal waste & $555 \mathrm{~m}^{3}$ & $13.2 \%$ \\
\hline Driftwood & $308 \mathrm{~m}^{3}$ & $7.3 \%$ \\
\hline Other organic material & $3342 \mathrm{~m}^{3}$ & $79.5 \%$ \\
\hline
\end{tabular}

Source: Compiled by the author based on data from the Middle Tisza District Water Directorate (KÖTIVIZIG).

Table 2. Composition of extracted waste as a percentage by weight

\begin{tabular}{|c|c|}
\hline \multicolumn{2}{|c|}{ Composition of extracted waste as a percentage by weight } \\
\hline Class & $24 \%$ \\
\hline Plastic wrapping & $48 \%$ \\
\hline Other plastic waste & $22 \%$ \\
\hline Rubber & $5 \%$ \\
\hline Metal wrapping & $1 \%$ \\
\hline
\end{tabular}

Source: Compiled by the author based on data from the Middle Tisza District Water Directorate (KÖTIVIZIG). 
Waste extracted and selected from the upstream side of the Kisköre Dam, the River Tisza and certain areas of Lake Tisza was transported to the waste dump of Tiszafüred, operated by NHSZ Tisza Nonprofit Kft. Waste collected into plastic bags on the lower sections of the river was taken to the dump of NHSZ Szolnok Public Service Provider Nonprofit Ltd. (NHSZ Szolnok Közszolgáltató Nonprofit Kft.).

\section{Works done in 2019}

During the spring of 2019 there were smaller but more durable flood waves coming down on the River Tisza. As the water level did not exceed the value where the Kisköre Dam gets opened, the driftwood mixed with communal waste started jamming at the upstream of the dam. As a result of the long accumulation period, the amount of driftwood got significant even in comparison with earlier years, which increased the risk of secondary environmental damage (dissolving, creation of microplastic). The amount and composition of the extracted driftwood and waste is shown in Tables 3 and 4.

Table 3. Quantity and composition of waste extracted after the 2019 spring flood

\begin{tabular}{|c|c|c|}
\hline \multicolumn{2}{|c|}{ Quantity and composition of waste extracted after the 2019 spring flood } \\
\hline Communal waste & $436 \mathrm{~m}^{3}$ & $4.7 \%$ \\
\hline Driftwood & $557 \mathrm{~m}^{3}$ & $6.0 \%$ \\
\hline Other organic material & $8254 \mathrm{~m}^{3}$ & $89.3 \%$ \\
\hline
\end{tabular}

Source: Compiled by the author based on data from the Middle Tisza District Water Directorate (KÖTIVIZIG).

Table 4. Composition of extracted waste as a percentage by weight

\begin{tabular}{|c|c|}
\hline \multicolumn{2}{|c|}{ Composition of extracted waste as a percentage by weight } \\
\hline Glass & $8 \%$ \\
\hline Plastic wrapping & $71 \%$ \\
\hline Other plastic waste & $17 \%$ \\
\hline Rubber & $3 \%$ \\
\hline Metal wrapping & $1 \%$ \\
\hline
\end{tabular}

Source: Compiled by the author based on data from the Middle Tisza District Water Directorate (KÖTIVIZIG).

After extracting driftwood and waste from the upstream of the dam, the material got shipped to the winter port of Kisköre for unloading. The route is shown on Figure 2. 


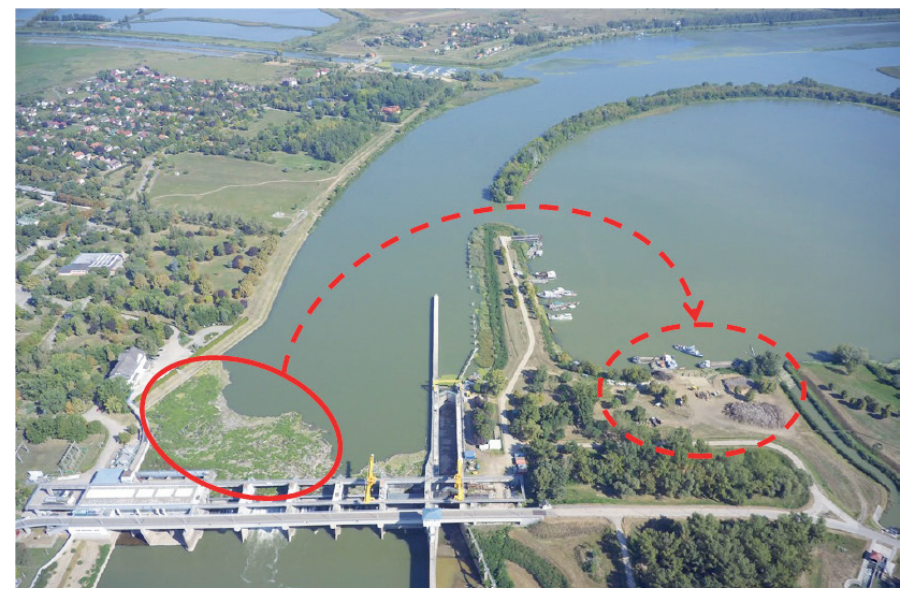

Figure 2. Place of collection, transport route and place of selection

Source: Compiled by the author based on graphics from Gábor Tóth, Middle Tisza District Water Directorate (KÖTIVIZIG).

The process of collection and the decreasing of the jamming that reached up to 1.7 hectares is shown in Figure 3.

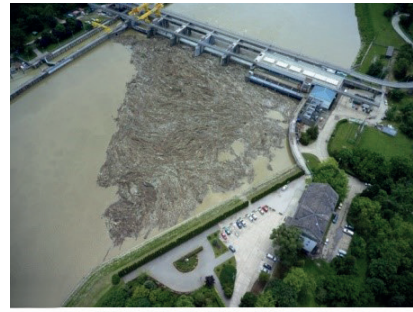

05.28 .2019

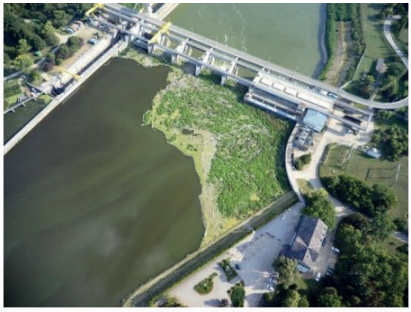

01.28.2019.

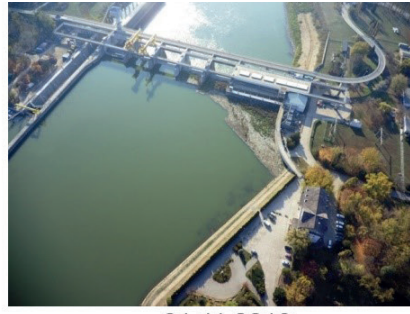

01.11.2019.

Figure 3. Removal process

Source: Compiled by the author based on graphics from Gábor Tóth, Middle Tisza District Water Directorate (KÖTIVIZIG).

Collection and unloading is done by a rotating loader mounted on a floating body, transportation is made by barges. The selection of the unloaded material is done on site. Usable driftwood is distributed among the surrounding communities by the local municipalities based on social needs. Selected waste is categorised and pressed before transportation.

Organic waste is shredded and reused. Similarly to 2017 the - non-recyclable - waste extracted and selected from the upstream side of the Kisköre Dam, River Tisza and certain areas of Lake Tisza was transported to the waste dump of Tiszafüred, operated by NHSZ Tisza Public Service Provider Nonprofit Ltd. (NHSZ Tisza Nonprofit Kft.). Glass was transported by EGRI Iron Ltd. (EGRI Fém Kft.), with their own trucks. Selected PET bottles were pressed and baled by the representatives of the Association of Environmental Enterprises. 


\section{Summary of experience and comparison with earlier data}

Data for comparison is available from 2007. They are shown in Table 5.

Table 5. Characteristic data of the waste extracted within the framework of environmental remediation activities in the period 2007-2019

\begin{tabular}{|c|c|c|c|c|c|c|c|c|c|c|}
\hline \multicolumn{11}{|c|}{ Main data of waste and driftwood extraction from the River Tisza (2004-2017) } \\
\hline \multirow{2}{*}{\multicolumn{3}{|c|}{ Year of operation }} & \multirow{3}{*}{$\begin{array}{c}\text { Total } \\
\text { extrac- } \\
\text { ted }\left(\mathrm{m}^{3}\right)\end{array}$} & \multicolumn{4}{|c|}{ Extracted material } & \multirow{3}{*}{$\begin{array}{c}\text { Proportion } \\
\text { of commu- } \\
\text { nal waste } \\
\text { in total } \\
\text { extracted } \\
\text { material }\end{array}$} & \multirow{3}{*}{$\begin{array}{l}\text { Total cost } \\
(\mathrm{Ft})\end{array}$} & \multirow{3}{*}{$\begin{array}{c}\text { Efficiency } \\
\left(\mathrm{Ft} / \mathrm{m}^{3}\right)\end{array}$} \\
\hline & & & & \multicolumn{2}{|c|}{$\begin{array}{c}\text { Communal } \\
\text { waste }\end{array}$} & \multirow{2}{*}{$\begin{array}{c}\text { Usable } \\
\text { driftwood } \\
\left(\mathrm{m}^{3}\right)\end{array}$} & \multirow{2}{*}{$\begin{array}{c}\text { Other } \\
\text { organic } \\
\text { material } \\
\left(\mathrm{m}^{3}\right)\end{array}$} & & & \\
\hline Year & Period & $\begin{array}{c}\text { Duration } \\
\text { (days) }\end{array}$ & & $\left(m^{3}\right)$ & $(\mathrm{t})$ & & & & & \\
\hline 2007 & 5-21 December & 13 & 783 & 35 & 6.64 & 196 & 552 & 4.47 & $9,010,000$ & 11,507 \\
\hline 2009 & $\begin{array}{c}17 \text { April - } \\
15 \text { May }\end{array}$ & 28 & 931 & 84 & 7.06 & 162 & 685 & 9.02 & $7,200,000$ & 7,734 \\
\hline 2010 & $\begin{array}{l}12 \text { April - } \\
12 \text { May }\end{array}$ & 30 & 446 & 76 & 7.04 & 65 & 305 & 17.04 & $4,667,000$ & 10,464 \\
\hline 2011 & $\begin{array}{l}24 \text { August - } \\
23 \text { September }\end{array}$ & 30 & 491 & 23 & 2.62 & 63 & 405 & 4.68 & $2,496,300$ & 5,084 \\
\hline 2012 & $\begin{array}{l}5 \text { April - } \\
11 \text { June }\end{array}$ & 66 & 1,473 & 145 & 9.15 & 182 & 1,146 & 9.84 & $13,233,700$ & 8,984 \\
\hline 2012 & $\begin{array}{c}9 \text { July - } \\
28 \text { August }\end{array}$ & 50 & 1,271 & 66 & 4.44 & 79 & 1,126 & 5.19 & $8,380,301$ & 6,593 \\
\hline 2013 & $\begin{array}{c}21 \text { May - } \\
10 \text { September }\end{array}$ & 112 & 1,127 & 150 & 12.68 & 82 & 895 & 13.31 & $5,696,699$ & 5,055 \\
\hline 2014 & $\begin{array}{c}2 \text { July - } \\
15 \text { August }\end{array}$ & 44 & 898 & 21 & 1.6 & 58 & 819 & 2.34 & $4,597,899$ & 5,120 \\
\hline 2015 & $\begin{array}{c}22 \text { April - } \\
15 \text { September }\end{array}$ & 147 & 4,238 & 154 & 9.22 & 433 & 3,651 & 3.63 & $10,211,111$ & 2,409 \\
\hline 2017 & $\begin{array}{l}15 \text { February - } \\
15 \text { September }\end{array}$ & 212 & 4,205 & 555 & 29.84 & 308 & 3,342 & 13.20 & $18,752,086$ & 4,459 \\
\hline 2019 & $\begin{array}{c}14 \text { June - } \\
19 \text { December }\end{array}$ & 188 & 9,247 & 436 & 0.0 & 557 & 8,254 & 4.72 & $67,730,000$ & 7,325 \\
\hline Total & & & 25,110 & 1,745 & 90.29 & 2,185 & 21,180 & & $151,975,096$ & \\
\hline
\end{tabular}

Source: Compiled by the author based on data from the Middle Tisza District Water Directorate (KÖTIVIZIG).

After analysing the data of Table 5, it becomes clear that the amount of extracted waste is continuously increasing. This can be the result of several factors including the efficiency of extraction or the level and duration of flood waves, which is affecting the quantity of grabbed driftwood and waste. However, it can be confidently stated that illegal waste dumping has not decreased in the catchment area. At present, we are not aware of any intention as a consequence of which any improvement could be expected in this field, and taking the events threatening the territorial sovereignty of Ukraine into consideration, which makes up as much as 25 per cent of the catchment area, we cannot expect any changes. 
Quantity of communal waste $\left(\mathrm{m}^{3}\right)$

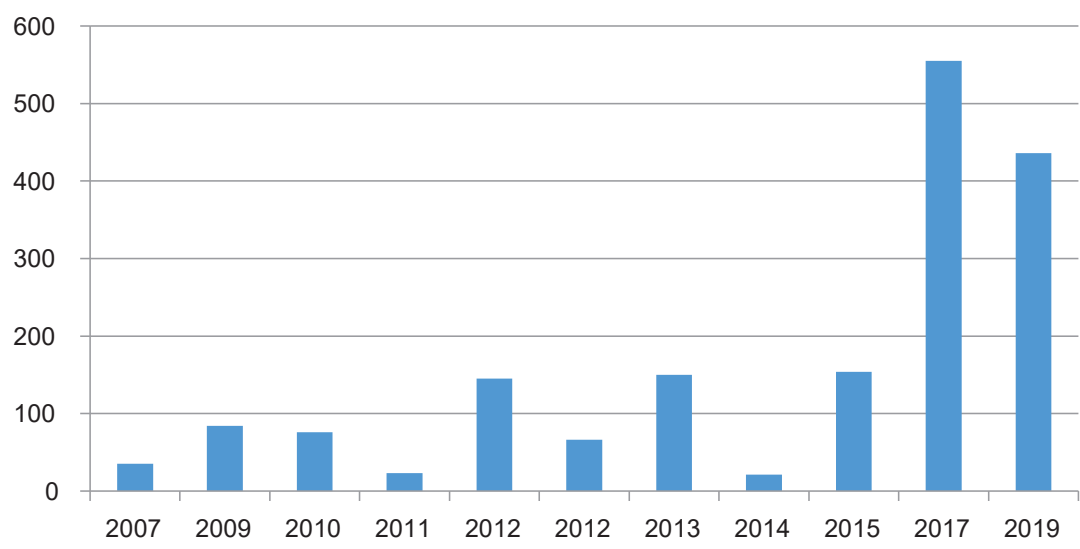

Figure 4. Amount of domestic waste collected per protection period

Source: Compiled by the author based on data from the Middle Tisza District Water Directorate (KÖTIVIZIG).

Maybe it can give us some confidence that the proportion of waste selected form the driftwood compared to the total amount is decreasing. This is shown in Figure 5, where values might show divergence due to the above mentioned reasons - efficiency of collection, level and duration of floods - but the trendline calculated from the averages clearly keeps to a negative direction, which shows a tendency of decrease.

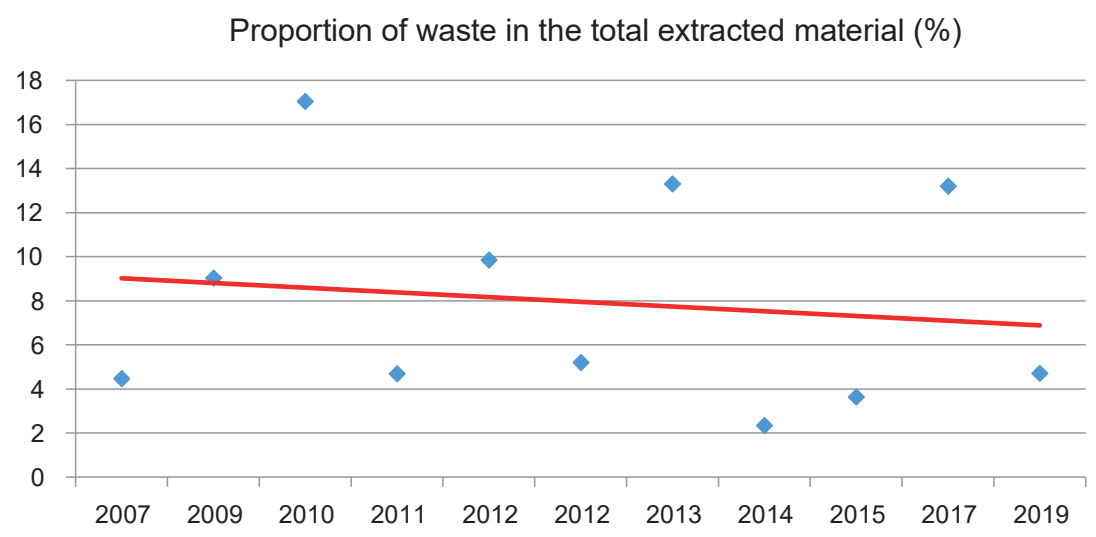

Figure 5. The ratio of waste to total extracted materials

Source: Compiled by the author based on data from the Middle Tisza District Water Directorate (KÖTIVIZIG).

It is worth looking at the costs as well, since it was impossible to pass them on and thus they are expected to be covered by the Hungarian Government in the future, too. The costs rising in each operation period is shown by the values marked with blue in Figure 6. 
In the beginning, they hardly exceeded 10,000,000 HUF and they did not significantly differ in the certain operation periods, they shaped in proportion with the amount of the waste. In the last two periods $(2017,2019)$ - which significantly exceeded the earlier events both in volume and duration - the costs became disproportionately high. On the other hand, efficiency (yellow in Figure 6) was continuously improving together with the continuous decrease of the cost per extracted $\mathrm{m}^{3}$. This can be the result of the experience of the personnel involved; however, this trend seems to break in the case of driftwood and waste, significantly exceeding the average of earlier years in volume. Both indicate that protracted damage protection from large volume driftwood and waste increases costs exceeding the proportional extent. One possible reason is that earlier operations took place in summer or early autumn so weather conditions were more favourable, while in 2017 operation started in early spring and lasted over the whole of summer, and in 2019 it started in the summer and ended early winter. This way in both cases there was activity in less favourable conditions which brought down efficiency. In addition, the size of the unloading port is limited, storing large amounts of material demands further transportation, scheduling and logistics and any problem in the execution will further decrease efficiency.

Cost and efficiency

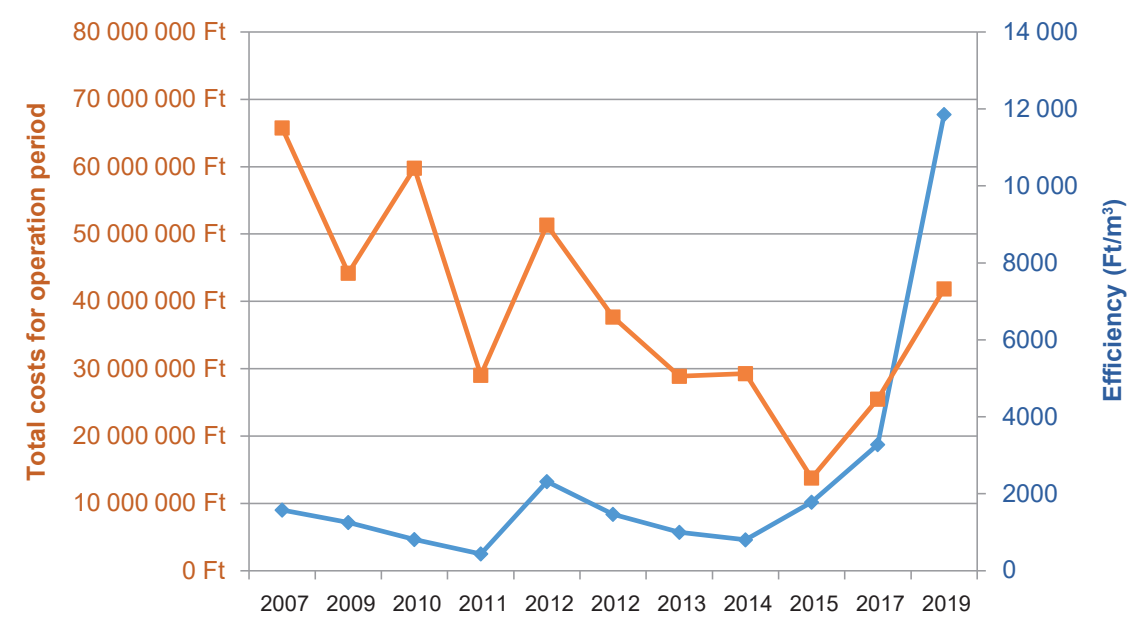

Figure 6. Development of costs and efficiency

Source: Compiled by the author based on data from the Middle Tisza District Water Directorate (KÖTIVIZIG).

\section{Development of the extraction of annually accumulated large volumes of driftwood and waste upstream of the Kisköre Dam}

In order to secure the extraction of annually accumulated driftwood and waste, to protect the dam, to increase the production of the power plant, to decrease pollution in the River Tisza (dissolving and microplastic) and to reduce epidemic danger (ASF), the area available for the operation needs to be enlarged. In addition - as the access is unpaved on more than 100 
meters - the stabilisation of the dirt road is also required to make us able to operate under all weather conditions, which would greatly increase efficiency. By building a selection hall, the process would be even more independent form the weather. For more efficiency, it is inevitable to renovate and replace the fleet used for shipping and loading. Based on Table 6, the average age of the machinery used is 33 years.

Table 6. Age of the vehicles used

\begin{tabular}{|c|c|}
\hline Type of machinery & Year of manufacturing \\
\hline Jégvirág VII ice breaking ship & 1976 \\
\hline Jégvirág VIII ice breaking ship & 1976 \\
\hline Z-2 barge & 1974 \\
\hline Z-3 barge & 1977 \\
\hline Floating crane II/Doosan loader & $1988 / 2015$ \\
\hline Floating crane IV/Poclain loader & $1988 / 1986$ \\
\hline Boat H-19438/Mercury15 & $1972 / 2013$ \\
\hline ACSM-D boat/Mercury40 & $1976 / 2011$ \\
\hline
\end{tabular}

Source: Compiled by the author based on data from the Middle Tisza District Water Directorate (KÖTIVIZIG).

The majority of machinery and tools is too old or not even available. There are 6 machines older than 40 years used for the extraction and loading. Using these means great extra costs and time loss as malfunctions are regular even despite of the timely maintenance.

If the accumulated driftwood exceeds the earlier amounts, fixing points should be created on the flood protection wall located in front of the power plant for the safe fixing of the machinery. Extraction can only be done safely with reduced power plant operation because of the significant suction produced by that. Limited operation results in decreased energy production, which makes it even more important to increase the efficiency of the extraction.

\section{Summary}

In spite of EU legal harmonisation, member states comply - or do not comply - with the regulations in accordance with and to the extent of their economical capacity. Consequently, there are significant deficiencies in waste management in the countries of the upper catchment area of the River Tisza, while growing consumption increased waste production in the last decades there, too. A part of the waste is dumped in the river valleys from where it floats together with driftwood, polluting the environment. Driftwood accumulated at the Kisköre Dam needs to be collected because of the large amount of waste contained inside; this task is getting harder and will soon exceed the capacity of the machinery and tools available, so development is inevitable.

In addition to the machinery, the operational area also needs to be developed as at the moment it does not provide any protection against weather. Small-scale works can be done under the right weather conditions, however, in case of operations lasting for several months, this is not an option because it is possible that, with other flood waves coming, the operation 
would take even more time - months or years. Both machinery and personnel are tied to this operation through its whole duration, which threatens carrying out their everyday basic duties.

With experience, new methods are arising in handling, utilising and storing waste. The large amount of driftwood that is not usable as firewood did not have a practical use so far, but selling it as shredded mulch as we did in the last few years can reduce costs.

However, the final and satisfactory solution would be the elimination of illegal communal waste dumps on the upper catchment area of the River Tisza. In order to ensure the good ecological state of the river, waste produced there should be managed professionally.

\section{References}

2008/98/EC Directive of the European Parliament and Council

2012. évi CLXXXV. törvény a hulladékról [Act CLXXXV of 2012 on Waste].

90/2007. (IV. 26.) Korm. rendelet a környezetkárosodás megelőzésének és elhárításának rendjéröl [Government Decree 90/2007 (IV.26.) on procedures for the prevention and remedying of environmental damage].

Daruka, Norbert, 'Jégvédekezés robbantással' [Ice protection by blasting]. Müszaki Katonai Közlöny 24, no 14 (2014), 51-67.

Gubek, István, 'A tengerek és óceánok mủanyag szennyezésének komplex hatása - 1. rész: A probléma bemutatása' [The complex impact of plastic pollution of the seas and oceans - Part 1: Description of the problem]. Természetvédelmi Közlemények 22 (2016), 33-61. Online: https://doi.org/10.20332/ tvk-jnatconserv.2016.22.33

Jambeck, Jenna R, Roland Geyer, Chris Wilcox, Theodore R Siegler, Miriam Perryman, Anthony Andrady, Ramani Narayan, Kara Lavender Law, 'Plastic waste inputs from land into the ocean'. Science 347, no 6223 (2015), 768-771. Online: https://doi.org/10.1126/science.1260352

Nagy, Nikoletta Tímea, A hulladékgazdálkodás szabályozásának újjogialapja [The New Legal Basis for the Regulation of Waste Management]. MA thesis, Miskolc, 2015. Online: http://midra.uni-miskolc. hu/document/19745/13698.pdf

Szabó, Ferenc, 'Implementációs kudarcok és kiigazítási kísérletek a hazai hulladékgazdálkodási politikában' [Implementation Failures and Adjustment Attempts in Domestic Waste Management Policy]. Taylor Gazdálkodás- és Szervezéstudományi Folyóirat 9, no 2 (2017), 56-67. Online. www. analecta.hu/index.php/taylor/article/view/13100/12956

Tarné Venczel, Ágnes, Környezettudatosságra nevelés az óvodában [Environmental Awareness Education in Kindergarten]. MA thesis, Miskolc, 2018. Online: http://midra.uni-miskolc.hu/document/29120/24939.pdf

Tóth, I János, A tiszai ciánszennyezés. Rendszerszemléletü elemzés [Systemic Analysis of the Tisza Cyanide Pollution]. Szeged, 2002. 